\title{
Predictive Value of Neutrophil-to-Lymphocyte and Platelet-to- Lymphocyte Ratio Measured Prior to Prostate Biopsy
}

\section{Prostat Biyopsisi Öncesi Ölçülen Nötrofil Lenfosit ve Trombosit Lenfosit Oranının Prediktif Değeri}

\author{
(D) Hüseyin Eren \\ Hüseyin Eren MD, Recep Tayyip Erdoğan University Faculty of Medicine, Department of Urology, Rize, Turkiye
}

\section{What's known on the subject? and What does the study add?}

The effect of inflammation parameters on prostate cancer has been shown previously. This study will examine the role of blood parameters on detecting clinically significant prostate cancer. Maybe, this may prevent to do unnecessary biopsy.

\section{Abstract}

Objective: We planned to investigate the value of neutrophil-to-lymphocyte ratio (NLR) and platelet-to-lymphocyte ratio (PLR) in predicting prostate cancer (PCa).

Materials and Methods: We enrolled 302 male patients who underwent prostate biopsy between January 2013 and June 2018 . We recorded anthropometric indices, demographic parameters, physical examination, laboratory values, in addition to results of radiologic imaging and pathological examination. The patients were divided into two groups as patients with benign prostatic hyperplasia (BPH) and those with PCa. We investigated the association of NLR and PLR with histopathology.

Results: The mean age of the patients was $66.2 \pm 8.2$ years. Patients with prostate adenocarcinoma were older, had higher prostate-specific antigen (PSA) concentrations, neutrophil count, and had lower hemoglobin, platelet count and prostate volume (PV) compared to patients with BPH. Receiver operating characteristic analysis identified that NLR values above 2.43 indicated 1.68 fold (95\% Cl: 1.06-2.66; $p=0.028)$ higher risk for prostate adenocarcinoma. NLR correlated positively with age, and PSA, negatively with hemoglobin and platelet count. NLR and PV were the independent predictors of biopsy histopathology.

Conclusion: We demonstrated that NLR is independently associated with PCa in patients undergoing prostatic biopsy due to high PSA levels.

Keywords: Neutrophil to lymphocyte ratio, Platelet to lymphocyte ratio, Prostate cancer, Benign prostatic hyperplasia

$\ddot{0} z$

Amaç: Prostat biyopsisi öncesinde nötrofil lenfosit oranı (NLR) ve trombosit lenfosit oranının (PLR) prostat kanserini öngörmede değerini araştırmayı planladık.

Gereç ve Yöntem: Ocak 2013 - Haziran 2018 tarihleri arasında prostat biyopsisi yapılan 302 hasta çalışmaya alındı. Antropometrik veriler, demografik özellikler, fizik muayene bulguları, laboratuvar değerleri, radyolojik görüntüleme sonuçları ve patolojik sonuçlar kaydedildi. Hastalar patoloji sonuçlarına göre benign prostat hiperplazisi (BPH) ve prostat kanseri olarak 2 gruba ayrıldı. NLR ve PLR histopatoloji sonucuna etkisi istatistiksel olarak karşılaştırıldı.

Bulgular: Hastaların yaş ortalaması $66,2 \pm 8,2$ yıl idi. Gruplar arasında yaş, nötrofil, hemoglobin, platelet, NLR, prostat-spesifik antijen (PSA) ve prostat volümü açısından anlamlı fark bulundu. Alıcı işletim karakteristiği analizinde NLR 2,43 üzerinde olan hastalarda prostat kanseri görülme olasılığının BPH'ye göre 1,68 (\%95 Cl: 1,06-2,66; $p=0,028)$ kat daha fazla olduğu izlendi. NLR ile yaş, nötrofil ve PSA arasında pozitif korelasyon, lenfosit, hemoglobin ve trombosit arasında negatif korelasyon saptandı. Çoklu analizde NLR ve PV'nin prostat kanseri için bağımsız belirteçler olduğu görüldü.

Sonuç: PSA değerinin yüksek olması nedeniyle prostat biyopsisi yapılan hastalarda NLR'nin prostat kanseri ile bağımsız bir şekilde ilişkili olduğu gösterildi.

Anahtar Kelimeler: Nötrofil lenfosit oranı, Trombosit lenfosit oranı, Prostat kanseri, Benign prostat hiperplazisi

Correspondence: Hüseyin Eren MD, Recep Tayyip Erdoğan University Faculty of Medicine, Department of Urology, Rize, Turkiye E-mail: huseyin.eren@erdogan.edu.tr ORCID-ID: orcid.org/0000-0002-1406-8781

Received: 15.12.2019 Accepted: 21.01.2020

Cite this article as: Eren H. Predictive Value of Neutrophil-to-Lymphocyte and Platelet-to-Lymphocyte Ratio Measured Prior to Prostate Biopsy. J Urol Surg 2020;7(1):37-41.

๑Copyright 2020 by the Association of Urological Surgery / Journal of Urological Surgery published by Galenos Publishing House. 


\section{Introduction}

Prostate cancer ( $\mathrm{PCa}), 15 \%$ of all cancers, is the second most common cancer in men, with approximately 1.1 million new diagnoses worldwide in 2012 (1). Therefore, several methods, such as digital rectal examination (DRE), prostate-specific antigen (PSA) screening, PSA density, PSA velocity and doubling time, PCa antigen 3 (PCA3) and multi-parametric magnetic resonance imaging ( $\mathrm{mpMRI}$ ) are used in clinical practice for early diagnosis $(2,3)$. PSA testing is the most commonly used screening method and a serum level above $4 \mathrm{ng} / \mathrm{mL}$ is generally accepted as an indication for prostate biopsy (4). The latest updated European Association of Urology guideline recommends the combination of 12-core biopsy and MR-guided fusion biopsy. However, today, transrectal ultrasonography (TRUS)-guided 12-core biopsy is still the standard technique used for the diagnosis of PCa (5).

Inflammation is one of the important factors in the etiology of carcinogenesis (6). In recent years, many studies demonstrated the relationship of blood biomarkers, such as neutrophil-tolymphocyte ratio (NLR) and platelet-to-lymphocyte ratio (PLR), with inflammation and immune response in cancer patients $(7,8)$. Circulating neutrophils and mediators, such as vascular endothelial growth factor, tumor necrosis factor $\alpha$, interleukin 1 (IL-1) and IL-6 may affect the progression of the cancer (9). Previous studies showed the relationship of NLR with overall survival, and progression-free survival (PFS) in patients with PCa $(10,11,12,13,14)$. Some studies identified elevated PLR as a poor prognostic factor in some cancers, such as gastric, ovarian, and renal cell cancer. In their study evaluating NLR and PLR in patients with BPH and PCa, Kaynar et al. (15) reported that a statistically significant difference was found in mean PLR between the groups only when the PSA level was $\geq 10 \mathrm{ng} / \mathrm{mL}$.

In the present study, we planned to investigate the value of NLR and PLR prior to prostate biopsy in predicting PCa.

\section{Materials and Methods}

We enrolled 447 male patients who were admitted to the urology clinic of our hospital between January 2013 and June 2018 with a PSA above $4 \mathrm{ng} / \mathrm{mL}$ and/or suspicious DRE findings that would necessitate prostate biopsy. We recorded patient information including anthropometric indices, demographic parameters, physical examination, laboratory values, in addition to results of radiologic imaging and pathological examination. Urine test was performed all patients to exclude urinary tract infection before biopsy procedure. Urine culture and antiobiogram were performed in patients with a sign of active infection. Patients who had negative culture after treatment and a PSA level above $4 \mathrm{ng} / \mathrm{mL}$ were also included. Enrolled patients underwent TRUS-guided 12-core prostate biopsy. All prostate biopsies were performed by the same urologist (Dr. H.E). Blood samples were collected via antecubital vein in the morning following an 8-hour fasting period. NLR and PLR were calculated using laboratory records.

We excluded patients with previous prostate biopsy $(n=12)$, prostatic surgery $(n=28)$, hematologic disorder $(n=6)$, oncologic disease $(n=13)$, history of radiotherapy $(n=5)$ and chemotherapy $(n=9)$, those using medications causing bone marrow suppression $(n=2)$ and patients who had high-degree intraepithelial neoplasia $(n=7)$, inflammation $(n=30)$, prostatitis $(28)$, and atypical small acinar proliferation in pathological examination. The remaining 302 patients, forming the study group, were further stratified as patients with $\mathrm{BPH}$ or $\mathrm{PC}$. Anthropometric indices, demographic characteristics, hematological values, and pathological results were compared between the groups.

The study was approved by the Recep Tayyip Erdoğan University Institutional Ethics Committee (2019/111) (Rize, Turkiye).

\section{Statistics Analysis}

Statistical analysis was performed using the Statistical Package for the Social Sciences (SPSS) 20.0 (IBM, Chicago, USA). Categorical values were displayed as percentages; continuous variables were expressed as mean \pm standard deviation The Kolmogorov-Smirnov test was used to evaluate the normality of the distributions of population. Since the distribution was not normal, Mann-Whitney U test with a Bonferroni correction test was used to compare the independent variables between the groups. Spearman analysis was used for correlation. We performed receiver operating characteristic (ROC) analysis to calculate threshold value for NLR. Multivariate analysis including independent variables [Body Mass index (BMI), age, smoking, prostate volume (PV)] of the univariate test was performed in order to demonstrate the effect of NLR on pathologic results. A $p$ value of $<0.05$ was considered statistically significant.

\section{Results}

The mean age of the patients was $66.2 \pm 8.2$ years. Anthropometric characteristics and laboratory values are presented in Table 1. Forty-three (14.2\%) patients were smokers. 153 patients (50.7\%) had $\mathrm{BPH}$, and the remaining 149 had prostatic adenocarcinoma. The PCa grade according to the International Society of Urologic Pathologists (ISUP) classification and Gleason score of patients with prostatic adenocarcinoma were as follows: ISUP $1(n=90)$ 29.8\%, ISUP $2(n=31) 10.3 \%$, ISUP $3(n=15) 5 \%$, ISUP $4(n=2)$ $0.7 \%$, ISUP $5(n=10) 3.3 \%$; Gleason $6(n=90) 29.8 \%$, Gleason $7(n=46) 15.2 \%$, Gleason $8(n=2) 0.7 \%$, and Gleason $9(n=10)$ $3.3 \%$, respectively.

ROC analysis identified a threshold of 2.43 (area under the curve: $0.584 ; 95 \% \mathrm{Cl}: 0.520-0.649, \mathrm{p}<0.001)$, with the sensitivity of 
$61.7 \%$, specificity of $51.6 \%$, positive predictive value of $55 \%$, and the negative predictive value of $58 \%$. NLR values above 2.43 indicated 1.68 times (95\% $\mathrm{Cl}=1.06-2.66 ; \mathrm{p}=0.028)$ higher risk of prostatic adenocarcinoma (Figure 1).

Patients with prostatic adenocarcinoma were older, had higher PSA concentrations, neutrophil count, and had lower hemoglobin, platelet count and PV compared to patients with BPH (Table 2). The remaining parameters were similar between the groups.

\begin{tabular}{|c|c|}
\hline Characteristics & Mean \pm SD \\
\hline Waist circumference, $\mathrm{cm}$, mean (SD) & $28.11 \pm 4.31$ \\
\hline WBC, mean (SD) & $8.37 \pm 3.48$ \\
\hline Neutrophil, mean (SD) & $5.74 \pm 3.07$ \\
\hline Lymphocyte, mean (SD) & $1.87 \pm 0.92$ \\
\hline Hemoglobin, mean (SD) & $13.25 \pm 2.45$ \\
\hline Platelet, mean (SD) & $230.01 \pm 74.70$ \\
\hline NLR, mean (SD) & $3.99 \pm 3.65$ \\
\hline PLR, mean (SD) & $150.98 \pm 116.29$ \\
\hline PSA ng/mL, mean (SD) & $18.48 \pm 73.21$ \\
\hline PV, mean (SD) & $70.01 \pm 39.16$ \\
\hline \multicolumn{2}{|c|}{$\begin{array}{l}\text { WBC: White blood cell, NLR: Neutrophil-to-lymphocyte ratio, PLR: Platelet-to- } \\
\text { lymphocyte ratio, PSA: Prostate-specific antigen, PV: Prostate volume, SD: Standarc } \\
\text { deviation }\end{array}$} \\
\hline
\end{tabular}

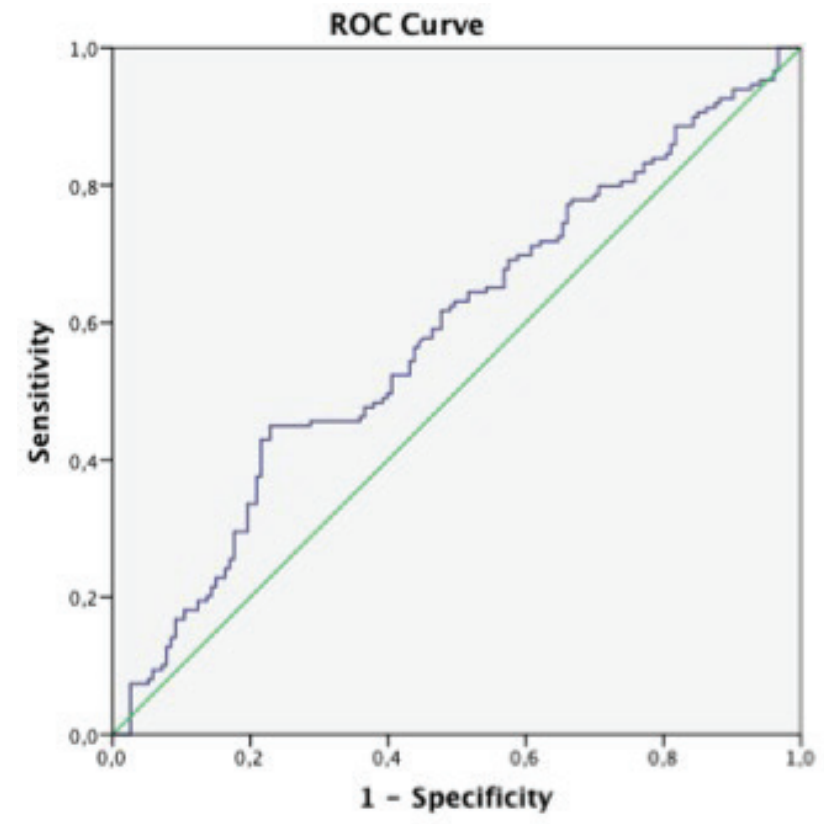

Figure 1. Neutrophil-to-lymphocyte ratio ROC curve of neutrophilto-lymphocyte ratio above 2.427 revealed $61.7 \%$ sensitivity and $51.6 \%$ specificity for prostatic carcinoma.

ROC: Receiver operating characteristic
Table 2. Comparison of anthropometric indices, demographic features and blood parameters between the groups

\begin{tabular}{|l|l|l|l|} 
& $\begin{array}{l}\text { BPH } \\
\mathbf{n}=\mathbf{1 5 3}(\mathbf{5 0 . 7 \% )}\end{array}$ & $\begin{array}{l}\text { Prostate Ca } \\
\mathbf{n}=\mathbf{1 4 9}(\mathbf{4 9 . 3} \%)\end{array}$ & $\mathbf{p}$ \\
\hline Age mean, (SD) & $64.98 \pm 7.77$ & $67.37 \pm 8.44$ & $\mathbf{0 . 0 1 7}$ \\
\hline BMI mean, (SD) & $28.28 \pm 3.99$ & $27.93 \pm 4.62$ & 0.292 \\
\hline WBC mean, (SD) & $8.02 \pm 3.02$ & $8.72 \pm 3.87$ & 0.179 \\
\hline Neutrophil mean, (SD) & $5.34 \pm 2.78$ & $6.16 \pm 3.29$ & 0.049 \\
\hline Lymphocyte mean, (SD) & $1.92 \pm 0.78$ & $1.81 \pm 1.05$ & 0.085 \\
\hline Hemoglobin mean, (SD) & $13.77 \pm 2.30$ & $12.72 \pm 2.50$ & 0.001 \\
\hline Platelet mean, (SD) & $241.37 \pm 78.88$ & $218.36 \pm 68.47$ & 0.006 \\
\hline NLR mean, (SD) & $3.62 \pm 3.71$ & $4.37 \pm 3.56$ & 0.011 \\
\hline PLR mean, (SD) & $152.32 \pm 136.61$ & $149.61 \pm 91.27$ & 0.932 \\
\hline PSA mean, (SD) & $7.35 \pm 7.27$ & $29.91 \pm 102.89$ & 0.001 \\
\hline PV mean, (SD) & $73.88 \pm 39.48$ & $66.05 \pm 38.56$ & 0.026 \\
\hline BPH: Bengn prstic hyp & &
\end{tabular}

BPH: Benign prostatic hyperplasia, Ca: Cancer, BMI: Body Mass index, WBC: White blood cell, NLR: Neutrophil-to-lymphocyte ratio, PLR: Platelet-to-lymphocyte ratio, PSA: Prostate.specific antigen, PV: Prostate volume, SD: Standard deviation

Spearman correlation analysis demonstrated a strong correlation between NLR and PLR ( $r=0.602)$. Additionally, NLR significantly positively correlated with age and PSA and negatively with hemoglobin and platelet count (Table 3).

We performed multivariate analyses including age, smoking, BMI, NLR and PV. We identified NLR and PV as the independent predictors of PCa (Table 4).

\section{Discussion}

In the present study, we investigated the relationship between the blood parameters and prostate biopsy histopathology. We demonstrated that increased age, neutrophil count, and NLR were associated with $\mathrm{PCa}$ and that $\mathrm{PCa}$ was more likely than $\mathrm{BPH}$ above a certain NLR threshold. Moreover, we demonstrated that NLR and PLR were strongly related. NLR correlated positively with age and PSA, negatively with hemoglobin and platelet count. However, only NLR and PV were the independent predictors of $\mathrm{PCa}$.

Elevated PSA levels and suspicious DRE are the main indications for prostate biopsy. TRUS-guided and MRI fusion biopsies are currently the most commonly used methods to detect PCa (5). Despite being specific for prostate, PSA may rise due to $\mathrm{BPH}$, prostatitis and trauma thus, may lead to unnecessary biopsy (16). Serial PSA testing, including PSA density, PSA velocity, PSA doubling time, free:total PSA ratio and PCA3 is used to avoid unnecessary biopsy procedures, however, none of them alone may reliably suggest definitive diagnosis of $\mathrm{PCa}$. Recent guidelines recommend additional imaging methods, such as mpMRI, which increase the cost of PCa diagnosis (5). We know that chronic inflammation and ensuing cell proliferation 
Table 3. Correlations between study parameters

\begin{tabular}{|c|c|c|c|c|c|c|c|c|c|c|}
\hline & Age & Neutrophil & Lymphocyte & Hemoglobin & Platelet & PSA & PV & NLR & BMI & PLR \\
\hline Age & 1 & & & & & & & & & \\
\hline Neutrophil & -0.010 & 1 & & & & & & & & \\
\hline Hemoglobin & $-0.227^{* *}$ & $-0.225^{* *}$ & $0.300^{* *}$ & 1 & & & & & & \\
\hline Platelet & $-0.140^{*}$ & 0.051 & $0.260^{* *}$ & $0.236^{* *}$ & 1 & & & & & \\
\hline PV & $0.207^{* *}$ & 0.037 & -0.040 & 0.011 & -0.040 & $0.237^{* *}$ & 1 & & & \\
\hline NLR & $0.143^{*}$ & $0.732^{* *}$ & $-0.664^{* *}$ & $-0.343^{* *}$ & $-0.124^{*}$ & $0.118^{*}$ & 0.056 & 1 & & \\
\hline BMI & $-0.205^{* *}$ & -0.083 & $0.141^{*}$ & $0.187^{* *}$ & 0.057 & $-0.151^{* *}$ & 0.025 & $-0.139^{*}$ & 1 & \\
\hline PLR & 0.085 & 0.062 & $-0.492^{* *}$ & -0.111 & $0.279^{* *}$ & 0.039 & 0,043 & $0.602^{* *}$ & -0.074 & 1 \\
\hline
\end{tabular}

Table 4. Logistic regression analysis to identify independent predictors of prostate cancer

\begin{tabular}{|l|l|l|l|}
\hline Independent variables & OR & $\mathbf{9 5 \%} \mathbf{C l}$ & $\mathbf{p}$ \\
\hline Age & 1.02 & $0.991-1.053$ & 0.17 \\
\hline Smoking & 1.01 & $0.506-2.017$ & 0.97 \\
\hline BMI & 1.00 & $0.996-1.012$ & 0.36 \\
\hline NLR & 1.12 & $1.025-1.227$ & 0.012 \\
\hline PV & $\mathbf{0 . 9 9}$ & $\mathbf{0 . 9 8 4 - 0 . 9 9 7}$ & $\mathbf{0 . 0 0 5}$ \\
\hline
\end{tabular}

BMI: Body Mass index, NLR: Neutrophil-to-lymphocyte ratio, PV: Prostate volume

contribute to carcinogenesis, and many cancers arise from sites of chronic inflammation (17). Since inflammation is implicated in carcinogenesis, blood biomarkers may be used in order to improve diagnosis of $\mathrm{PCa}$. Recently, inexpensive biomarkers, such as NLR, and PLR, are being used in predicting malignancies (18). In a Swedish cohort, it was documented that elevated prediagnostic inflammatory markers were significantly associated with $\mathrm{PCa}$, and high leukocyte count was related with increased risk of PCa in young men (19). Similarly, in a Finnish cohort, an increased PCa risk with high leukocyte count has been reported (20).

NLR is a sign of immune activity. Low lymphocyte count is associated with immunosuppression in several cancers (19). NLR is raised in patients with aggressive or high-grade tumors, which also reflects poor survival $(18,21)$. Although Kamali et al. (22) and Khosropanah et al. (23) could not document an association between NLR and PCa, several other studies identified a positive relationship and proposed to use NLR as a biomarker for the diagnosis of PCa $(2,16,24)$. Our study also supports this hypothesis.

Thrombocytosis is often encountered in malignant tumors with poor survival (25). The reason for that association may be evasive action of tumor cells from immune system by platelets. Platelets may also interact with tumor cells via ligands and help vascular adhesion of malignant cells (26). The relationship of PLR with $\mathrm{PCa}$ is not clear. A meta-analysis showed an association between PLR and overall and PFS (27). Yuksel at al. (9) and coworkers reported that a high PLR was a predictor of PC. We could not document an association between PCa and PLR in our study.

\section{Study Limitations}

The major limitation of the study was its retrospective design. Another important aspect is including only patients with BPH as the control group. Biopsy-proven prostatitis might be compared as well. However, our study includes two large groups with similar size, which is a strong aspect.

\section{Conclusion}

We demonstrated that NLR was independently associated with $\mathrm{PCa}$ in patients who underwent prostatic biopsy due to high PSA levels.

\section{Ethics}

Ethics Committee Approval: The study was approved by the Recep Tayyip Erdoğan University Institutional Ethics Committee (2019/111) (Rize, Turkiye).

Informed Consent: Informed consent was obtained from all patients

Peer-review: Externally peer-reviewed.

Conflict of Interest: No conflict of interest was declared by the authors.

Financial Disclosure: The author declare that they have no relevant financial. 


\section{References}

1. Ferlay J, Soerjomataram I, Dikshit R, Eser S, Mathers $C$, Rebelo M, Parkin DM, Forman D, Bray F. Cancer incidence and mortality worldwide: sources, methods and major patterns in GLOBOCAN 2012. Int J Cancer 2015;136:E359-386.

2. Guo J, Fang J, Huang X, Liu Y, Yuan Y, Zhang X, Zou C, Xiao K, Wang J. Prognostic role of neutrophil to lymphocyte ratio and platelet to lymphocyte ratio in prostate cancer: a meta-analysis of results from multivariate analysis. Int J Surg 2018;60:216-223.

3. Carter HB, Pearson JD, Metter EJ, Brant L, Chan DW, Andres R, Fozard JL, Walsh PC. Longitudinal evaluation of prostate-specific antigen levels in men with and without prostate disease. JAMA 1992;267:2215-2220.

4. Fujita $K$, Imamura R, Tanigawa G, Nakagawa M, Hayashi T, Kishimoto N, Hosomi M, Yamaguchi S. Low serum neutrophil count predicts a positive prostate biopsy. Prostate Cancer Prostatic Dis 2012;15:386-390.

5. EAU Annual Congress Barcelona 2019. ISBN 978-94-92671-04-2.

6. Diakos $\mathrm{Cl}$, Charles KA, McMillan DC, Clarke SJ. Cancer-related inflammation and treatment effectiveness. Lancet Oncol 2014;15:e493-503.

7. McMillan DC. Systemic inflammation, nutritional status and survival in patients with cancer. Curr Opin Clin Nutr Metab Care 2009;12:223-226.

8. Ropponen KM, Eskelinen MJ, Lipponen PK, Alhava E, Kosma VM. Prognostic value of tumour-infiltrating lymphocytes (TILs) in colorectal cancer. J Pathol 1997;182:318-324.

9. Yuksel $\mathrm{OH}$, Urkmez $\mathrm{A}$, Akan S, Yldirim C, Verit A. Predictive value of the platelet-to-lymphocyte ratio in diagnosis of prostate cancer. Asian Pac $J$ Cancer Prev 2015;16:6407-6412.

10. Yin X, Xiao Y, Li F, Qi S, Yin Z, Gao J. Prognostic role of neutrophil-tolymphocyte ratio in prostate cancer: a systematic review and meta-analysis. Medicine 2016;95.

11. Gu X, Gao X, Li X, Qi X, Ma M, Qin S, Yu H, Sun S, Zhou D, Wang W. Prognostic significance of neutrophil-to-lymphocyte ratio in prostate cancer: evidence from 16,266 patients. Sci Rep 2016;6:22089.

12. Wang DS, Ren C, Qiu MZ, Luo HY, Wang ZQ, Zhang DS, Wang FH, Li YH, $\mathrm{Xu} \mathrm{RH}$. Comparison of the prognostic value of various preoperative inflammation-based factors in patients with stage III gastric cancer. Tumour Biol 2012;33:749-756.

13. Asher V, Lee J, Innamaa A, Bali A. Preoperative platelet lymphocyte ratio as an independent prognostic marker in ovarian cancer. Clin Transl Oncol 2011;13:499-503.

14. Fox P, Hudson M, Brown C, Lord S, Gebski V, De Souza P, Lee CK. Markers of systemic inflammation predict survival in patients with advanced renal cell cancer. Br J Cancer 2013;109:147-53.

15. Kaynar M, Yildirim ME, Gul M, Kilic O, Ceylan K, Goktas S. Benign prostatic hyperplasia and prostate cancer differentiation via platelet to lymphocyte ratio. Cancer Biomark 2015;15:317-323.
16. Gokce MI, Hamidi N, Suer E, Tangal S, Huseynov A, Ibiş A. Evaluation of neutrophil-to-lymphocyte ratio prior to prostate biopsy to predict biopsy histology: Results of 1836 patients. Can Urol Assoc J 2015;9:E761-765.

17. Balkwill F, Mantovani A. Inflammation and cancer: back to Virchow? Lancet 2001;357:539-545.

18. Templeton $\mathrm{A}$, Ace $\mathrm{O}$, McNamara $\mathrm{MG}$, Al-Mubarak $\mathrm{M}$, Vera-Badillo $\mathrm{FE}$, Hermanns T, Seruga B, Ocaña A, Tannock IF, Amir E. Prognostic role of platelet to lymphocyte ratio in solid tumors: a systematic review and metaanalysis. Cancer Epidemiol Biomarkers Prev 2014;23:1204-1212.

19. Van Hemelrijck $M$, Jungner I, Walldius $G$, Garmo $H$, Binda $E$, Hayday $A$, Lambe M, Holmberg L, Hammar N. Risk of prostate cancer is not associated with levels of C-reactive protein and other commonly used markers of inflammation. Int J Cancer 2011;129:1485-1492.

20. Toriola AT, Laukkanen JA, Kurl S, Nyyssönen K, Ronkainen K, Kauhanen J. Prediagnostic circulating markers of inflammation and risk of prostate cancer. Int J Cancer 2013;133:2961-2967.

21. Guthrie GJ, Charles KA, Roxburgh CS, Horgan PG, McMillan DC, Clarke SJ. The systemic inflammation-based neutrophil-lymphocyte ratio: experience in patients with cancer. Crit Rev Oncol Hematol 2013;88:218-230.

22. Kamali K, Ashrafi M, Shadpour P, Ameli M, Khayyamfar A, Abolhasani M, Azizpoor A. The role of blood neutrophil count and the neutrophil-tolymphocyte ratio as a predictive factor for prostate biopsy results. Scand J Urol 2013;47:158-162.

23. Khosropanah I, Rostami S, Bateni ZH, Teimoori M, Khosrovpanah D. Prognostic Value of Neutrophil to Lymphocyte Ratio on Pathologic Findings of Transrectal Ultrasonography Guided Biopsy of Prostate. Iran J Pathol 2018;13:333-339.

24. Huang T-b, Mao S-y, Lu S-m, Yu J-j, Luan Y, Gu X, Liu H, Zhou GC, Ding XF. Predictive value of neutrophil-to-lymphocyte ratio in diagnosis of prostate cancer among men who underwent template-guided prostate biopsy: A STROBE-compliant study. Medicine (Baltimore) 2016;95:e5307.

25. Gu L, Li H, Gao Y, Ma X, Chen L, Li X, Zhang Y, Fan Y, Zhang X. The association of platelet count with clinicopathological significance and prognosis in renal cell carcinoma: a systematic review and meta-analysis. PLoS One 2015;10:e0125538.

26. Heng DY, Xie W, Regan MM, Warren MA, Golshayan AR, Sahi C, Eigl BJ, Ruether JD, Cheng T, North S, Venner P, Knox JJ, Chi KN, Kollmannsberger C, McDermott DF, Oh WK, Atkins MB, Bukowski RM, Rini BI, Choueiri TK. Prognostic factors for overall survival in patients with metastatic renal cell carcinoma treated with vascular endothelial growth factor-targeted agents: results from a large, multicenter study. J Clin Oncol 2009;27:57945799.

27. Wang J, Zhou X, He Y, Chen X, Liu N, Ding Z, Li J. Prognostic role of platelet to lymphocyte ratio in prostate cancer: A meta-analysis. Medicine (Baltimore) 2018;97:e12504. 